\title{
THE EFFECT OF FINANCIAL PERFORMANCES ON EARNINGS QUALITY OF SERBIAN HOTELS
}

\author{
Ivana Bešlić Rupić1 ${ }^{10}$ \\ Dragana Bešlić Obradović ${ }^{2}$ (D) \\ Bojan Rupić ${ }^{3}$
}

DOI: https://doi.org/10.31410/tmt.2020.333

\begin{abstract}
This study examines the effect of financial performances on earnings quality using a sample of Serbian hotels during the period 2015-2019. First, the authors build a multidimensional measure of earnings quality including attributes as the hotel's going concerned, size, current liquidity, age, profitability, and leverage. Second, the authors examine variables that are potentially associated with earnings quality. The methodology includes descriptive statistics, univariate test, correlation matrix for the variables, multivariate regression, $F$-test. This paper presents managerial implications for professionals, users of financial statements, and academics.
\end{abstract}

Keywords: Earnings quality, Earnings management, Financial performances, Serbian hotels.

\section{INTRODUCTION}

$\mathrm{T}$ he Serbian accounting system is based on International Accounting Standards - IAS/International Financial Reporting Standards - IFRS and on the Law on Accounting and the Law on Auditing and other regulations imposed by the Government and Ministry of Finance. The World Bank Report on Compliance with Regulations and Standards in the Field of Accounting (Report on the Observance of Standards and Codes - ROSC Serbia), published in June 2015, notes significant progress in the reform of accounting regulations that have been achieved by the current Accounting Law and the Law on Audit adopted by Serbia in July 2013 compared to 2005, when there was a preliminary examination, but also noticed are certain shortcomings. Key weaknesses relate to the following (Center for the Financial Reporting Reform, 2015):

1. The institutional financial reporting system has many weaknesses,

2. Legal bases of financial reporting are incompatible with EU requirements,

3. Weaknesses of the education system and further training of professionals based on financial reporting practices.

Financial reports are used to convey financial information on firm performance. Sometimes the management of the company takes advantage of accounting choices to manipulate earnings and mislead users. However, managers could choose reporting methods to reflect the financial figures to their advantage to temporarily either inflate or reduce the firm's current income to meet a predetermined target. One of these accounting practices is called earnings management manipulation (Hai-Yen, Li-Heng, \& Hui-Fun, 2019). The practice of earnings management is a way for managers to use accounting standards to meet specific objectives, without breaking the accounting principles.

Alfa BK University, 3 Palmira Toljatija, 11070 Belgrade, Serbia

Alfa BK University, 3 Palmira Toljatija, 11070 Belgrade, Serbia

Kapital revizija doo, 1 Vojvode Mišića, 21000 Novi Sad, Serbia 
The remainder of this paper has been organized as follows. In the next section, we present the literature review and hypotheses development. In section 3 we focus on the research methodology adopted for the study; while sections 4,5 , and 6 discuss the empirical results, the conclusion of the study, and future research directions.

\section{LITERATURE REVIEW}

The academic literature has numerous definitions of earnings quality.

1. Based on earnings stability: The more sustainable the earnings, the higher the quality of earnings (Tapia \& Fernández, 2011).

2. Based on information content: Kirschenheiter and Melumad (2004) state that high-quality earnings are more informative and closer to the long-run value of the firm.

Several measures of earnings quality are proposed in the literature. The Miller (2009) approach is used to measure this variable. The relationship is to be known as the MR (Miller Ratio) and specified as $\triangle \mathrm{WC} / \mathrm{CFO}$ (change in working capital/cash flow from operations). Specifically, the further from zero the MR is, the more probability of earnings management, since it detects discretionary accruals. It is the level of discretionary accruals that suggest earnings management. Chan et al. (2006) find that increased earnings accompanied by high accruals suggest low earnings quality.

Earnings management is defined as a process to manipulate data and numbers legally exploiting the flexibility of the international accounting standards (IAS) to show an unreal picture of the content of financial statements and in contrary with the real condition of the company's performance to achieve their management interests. Earnings management refers to a strategy used by a firm's management to apply accounting rules flexibly to manipulate corporate profits (Bodie, Kane, \& Marcus, 2013).

The development of the global economy imposes a need for the harmonization of financial reporting. Quality financial reporting implies the application of accounting standards, that enable the comparability of financial reports within the international framework. International Accounting Standards/International Financial Reporting Standards (IAS/IFRS) was issued as a single set of global accounting standards to offer better transparency and comparability of the financial statement. Also, IAS/IFRS standards provide greater flexibility of accounting choices and subjective estimates (Biddle, Hillary, \& Verdi, 2009).

Extant literature suggests that IFRS improves the reliability of financial reporting by limiting opportunistic management discretion and increasing earnings quality (Aharony, Barniv, \& Falk, 2010; Djatej, Gao, Sarikas, \& Senteney, 2011; Burca, \& Mates, 2015). Other studies argue that the implementation of international regulation does not limit earnings management and does not improve earnings quality (Anwer, Michael, \& Dechun, 2013).

If profitability is extremely low, managers may decrease income, which is known as the "big bath' strategy (Healy, 1985). A „big bath" is an accounting term defined as "the attempt to increase reported earnings in subsequent periods by charging items that may have a negative future impact to expenses in the current period, further worsening current period business results in an accounting period in which results are bad" (Itoh 2007). 
Managers may decrease earnings to meet bonus targets or to protect their job, to control fluctuations in reported earnings, to assure investors of a steady earnings flow, etc. The companies with a low return on assets have a greater tendency to smooth earnings (Ratnanigrum, 2016). Koch (1981) defines that income smoothing as a method used by management to reduce fluctuations in reported earnings to match the desired target either artificial (artificial smoothing), and in real terms (real smoothing). Income smoothing is a common form of earnings management (EM) where managers can manipulate earnings in two directions, inflate or deflate net income so that income movement seems smoother and less fluctuated. Income smoothing could be classified as artificial, where techniques of accounting earnings management such as accruals manipulation could be implemented, or real, where methods of real earnings management could be applied such as sales of assets (Khalil, \& Simon, 2014). Jayaraman (2008) argues that income smoothing distorts the contemporaneous information content of earnings and cash flow.

There are many other reasons why and how managers manipulate, such as capital market pressure, managerial incentives, political connections, building credibility with the capital market, maintaining or increasing stock prices, improving the external reputation of the management team, to convey future growth prospects and unrealistic forecasting of revenues (Wijesinghe, \& Kehelwalatenna, 2017). Earnings management is regarded as an inverse measure of the earnings quality by representing a deliberate intervention in the financial statements, negatively impacting the earnings quality (Baxter, $\&$ Cotter, 2009). There is no clear consensus on a definition of earnings management in the literature.

Existing literature has different definitions of „earnings management”. Schipper (1989) defined earnings management as ,a purposeful intervention in the external financial reporting with the intent of obtaining some private gain.” According to Healy (1999) „,earnings management occurs when managers use judgment in financial reporting and in structuring transactions to alter financial reports to either mislead some stakeholders about the underlying economic performance of the company or to influence contractual outcomes that depend on reported accounting practices." Scott (2009) determines earnings management as ,the choice of accounting policies or actions that can affect earnings to achieve a specific objective." According to Scott (2009) various earnings management tactics are: 1) the big bath, 2) income minimization, 3) income maximization, and 4) income smoothing.

Earnings management is a purposeful intervention in financial reporting, designed to reach earnings targets by varying accounting practices. However, it is an action that takes place without necessarily violating accounting regulations, and which takes advantage of possibilities of choice in accounting policy. The action may mislead stakeholders, causing them to make decisions based on financial reports that they would not have made otherwise (Callao, Jarne, \& Wroblewski, 2014a, 2014b).

Earnings management may arise from information asymmetry problems and agency conflicts (Deegan, 1996, Watts, \& Zimmerman, 1986). Earnings management is an attempt by managers to alter financial reports either for their private benefits or for the benefits of the stockholders. Prior studies identified different incentives for earnings management, such as management compensation, income-smoothing motivation, meeting or beating the earnings expectations of analysts, avoiding debt covenant violation, regulatory incentives, and earnings management performed to avoid financial distress (Rahman, Moniruzzaman, \& Sharif, 2013; Ronen, \& Tzur, 2006; Iatridis, \& Kadorinis, 2009; Watts \& Zimmerman, 1990; Wruck, 1990).

Concerning Altman's Z-Score which is founded on the strength of firms' balance sheets, it is likely that healthy firms have higher earnings quality than bankrupt firms, and therefore these firms' catego- 
ries are significantly different because the strength of accounting-based information is more important in determining earnings quality attributes (Barker, \& Imam, 2008).

Financial distress was measured using Altman Z-Score according to Altman (1968). Prediction of the company's financial condition according to Altman (1968) can be seen from the value of the Z-Score with the following conditions:

1. For a Z-Score smaller than 1.80 , it means that the company is experiencing financial difficulties and the risk of bankruptcy is high.

2. For the Z-Score value between 1.80 and 2.99 , the company is considered to be in the gray area. In this area, there is a possibility that the company will go bankrupt, and some will not.

3. For the value of Z-Score greater than 2.99, give an assessment that the company is in a very healthy state so the possibility of bankruptcy is very small.

The research conducted by Indracahya and Anggraini (2017) shows that good corporate governance has a significant influence on earnings management and the effect is negative. Leverage and profitability have a significant influence on earnings management and the effects that are generated are positive. The age of the company does not have a significant effect on earnings management. Company size does not have a significant effect on earnings management. Previous research studies show that the size of a company could have both positive and negative relationships with earnings management/discretionary accruals (Becker et al., 1998; Chung, Firth, $\&$ Kim, 2002). High liquidity allows the manager in the absence of a proper management structure of the company to manipulate profit (earnings) (Gombolaa, Amy, \& Chin-Chuan, 2016). Mohammadi and Amini (2016) show results that financial distress and earnings management has a positive and significant relationship. Roychowdhury (2006) found evidence that managers manipulate real activities to avoid reporting annual losses.

Hotels in AP Vojvodina were profitable for the period 2014-2018. The average value of return on assets (ROA) is $32.56 \%$. The empirical analysis reflected that total revenues increased by $218.18 \%$, while total expenses grew by far less intensity and their growth was $123.47 \%$ for the observed period. It can be concluded that total revenues have almost doubled to total expenses of analyzed hotels in AP Vojvodina and this fact can confirm that these hotels are profitable for the period 2014-2018 (Kalaš, Mirović, \& Pavlović, 2019).

Firms located in more developed countries and common-law countries are associated with a lower level of earnings management, which is consistent with previous research on the determinants of earnings management worldwide (Ball, Robin, \& Wu, 2003; Leuz, Nanda, \& Wysocki, 2003; Gaio, 2010). The hotel industry shows higher sales volatility, higher incidence of losses, and lower earnings quality (Parte-Esteban, \& Garcia, 2014). However, not much is known about the incentives to earnings management in this industry (Park, \& Jang, 2014). We aim to fill this gap in the literature, by analyzing the firm characteristics that play an important role in explaining the level of earnings management in the hotel industry.

This study aims to understand the impact of firm characteristics/financial performances on the earnings quality of Serbian hotels. Two research questions were asked:

1. Does the earnings management exist among Serbian hotels in the sample?

2. Do factors such as financial performances affect the earnings quality of hotels in Serbia? 
These arguments suggest our first hypothesis:

Hypothesis One: Serbian hotels have low quality of accounting earnings during the period 2015-2019.

The main objective of this paper is to investigate the influence of firm-specific characteristics on earnings quality in Serbian hotels.

Hypothesis Two: $\quad$ Financial performances of Serbian hotels are associated with the quality of accounting earnings.

In order to examine our two hypotheses, we developed the following regression model:

$$
E Q=\beta_{0}+\beta_{1} \times Z \text {-Score }+\beta_{2} \times S Z+\beta_{3} \times C L+\beta_{4} \times A G+\beta_{5} \times R O A+\beta_{6} \times L E V+\varepsilon
$$

Where:

$E Q=$ Quality of accounting earnings;

$Z$-Score $=$ Hotel's going concern;

$S Z=$ Hotel's size;

$C L=$ Current liquidity;

$A G=$ Hotel's age;

$R O A=$ Return on assets;

$L E V=$ Leverage;

$\beta_{0}, \beta_{2} \ldots \beta_{6}=$ Hotel-specific parameters;

$\varepsilon=$ Residual.

\section{DATA AND METHODOLOGY}

In this research secondary data was used which was obtained from Scoring ("Scoring", 2020) and based on the single financial statement's data of 20 hotels/ business entities registered in Serbia from the years 2015 to 2019 (Table 1). This period was chosen because it is the period after mandatory IFRS adoption by Serbian companies. The final sample has 100 firm-year observations. The available data is processed using the statistical software SPSS (Statistical Package for Social Sciences) IBM Statistics Version 20.

Table 1. Review of the explanatory variables

\begin{tabular}{|c|c|c|c|}
\hline Symbol & Variable & Description & Source \\
\hline \multicolumn{4}{|c|}{ Dependent variable } \\
\hline EQ & $\begin{array}{l}\text { Earnings } \\
\text { quality }\end{array}$ & $\begin{array}{l}\text { Earnings quality measured by Miller ratio }=\Delta \text { ( } \triangle \text { Change in net } \\
\text { working capital/Cash flows from operating activities) } \\
\text { In the absence of earnings management, the result of the equation } \\
\text { will be as follows: } \\
(\triangle W C / C F O) \mathrm{t} /(\triangle W C / C F O)_{\mathrm{t}-1}=0 \\
\text { In the case of earnings management (low quality of earnings) the } \\
\text { result of the equation will be as follows: } \\
(\triangle W C / C F O) \mathrm{t} /(\triangle W C / C F O)_{\mathrm{t}-1} \neq 0\end{array}$ & $\begin{array}{l}\text { Authors } \\
\text { calculation }\end{array}$ \\
\hline
\end{tabular}




\begin{tabular}{|c|c|c|c|}
\hline \multicolumn{4}{|c|}{ Independent variable } \\
\hline Z-Score & $\begin{array}{l}\text { Hotel's } \\
\text { going } \\
\text { concern }\end{array}$ & $\begin{array}{l}\text { Z-Score measured by Edward Altman }(1968)=1.2 \times X_{1}+1.4 \times X_{2} \\
+3.3 \times X_{3}+0.6 \times X_{4}+0.999 \times X_{5 ;} \\
\text { Where: } \\
\mathrm{X}_{1}=\text { Working capital/Total assets } \\
\mathrm{X}_{2}=\text { Retained earnings/Total assets } \\
\mathrm{X}_{3}=\text { Earnings before interest and taxes (EBIT)/Total assets } \\
\mathrm{X}_{4}=\text { Market value of equity/Book value of debt } \\
\mathrm{X}_{5}=\text { Sales/Total assets } \\
\text { - According to this model, the company is persistent if the value } \\
\text { of } \mathrm{Z} \text { is greater than or equal to } 3 \text { (indicating healthy hotels) } \\
\text { - The hotel is doubtful if the value of } \mathrm{Z} \text { is between } 1.80 \text { to } 2.99 \text {, } \\
\text { (indicating financially distressed hotels and a high probability } \\
\text { of going bankrupt) } \\
\text { - The company's continuity is threatened if the value of } \mathrm{Z} \text { is less } \\
\text { than or equal to 1.8. (indicating bankrupt hotels) }\end{array}$ & $\begin{array}{l}\text { Authors } \\
\text { calculation }\end{array}$ \\
\hline SZ & Size & Natural logarithm of the total assets & $\begin{array}{l}\text { Authors } \\
\text { calculation }\end{array}$ \\
\hline $\mathrm{CL}$ & $\begin{array}{l}\text { Current } \\
\text { liquidity }\end{array}$ & Current assets/Current liabilities & $\begin{array}{l}\text { Authors } \\
\text { calculation }\end{array}$ \\
\hline $\mathrm{AG}$ & Age & Natural logarithm of the hotel age & $\begin{array}{l}\text { Authors } \\
\text { calculation }\end{array}$ \\
\hline ROA & $\begin{array}{l}\text { Return on } \\
\text { assets }\end{array}$ & Net income/ Total assets & $\begin{array}{l}\text { Authors } \\
\text { calculation }\end{array}$ \\
\hline LEV & Leverage & Total debt/Total assets & $\begin{array}{l}\text { Authors } \\
\text { calculation }\end{array}$ \\
\hline
\end{tabular}

Source: Authors' illustration

Table 2. List of the analyzed Serbian hotel companies

\begin{tabular}{|c|l|c|}
\hline No. & Name of the hotel company & Size of the hotel company \\
\hline 1. & Crystal doo Beograd & small \\
\hline 2. & Euro Garni Hotel doo Beograd -Zemun & small \\
\hline 3. & HTP Plaža doo Beograd & small \\
\hline 4. & Hotel Elegance doo Beograd & small \\
\hline 5. & Hotel Novi Sad doo Novi Sad & medium \\
\hline 6. & Hotel Putnik Beograd doo Beograd -Novi Beograd & micro \\
\hline 7. & Hoteli Palisad Zlatibor & small \\
\hline 8. & Hoteli Tri O doo Topola & small \\
\hline 9. & HTP Olimp Zlatibor & small \\
\hline 10. & HTP Srbija doo Vršac & micro \\
\hline 11. & Hotel Park ad Novi Sad & medium \\
\hline 12. & Kopernikus Hotel Prag doo & medium \\
\hline 13. & Majdan Luks doo Beograd & medium \\
\hline 14. & Hotel Majestic doo Beograd & medium \\
\hline 15. & Metropol Palace doo Beograd & medium \\
\hline 16. & Prezident doo Novi Sad & small \\
\hline 17. & Slavija Hoteli doo Beograd & Serbia \\
\hline 18. & Svetlost doo Niš & \\
\hline 19. & Todor Hotels doo Beograd & \\
\hline 20. & AD Hotel Srbija Beograd & Replium \\
\hline & & \\
\hline
\end{tabular}

Source: Business Registers Agency of the Republic of Serbia

Basically, the size of the hotel company is only divided into 3 categories: 1. medium companies, 2. small companies, and 3. micro enterprises (Table 2). Selected hotels use IFRS/IAS in the process of financial statement preparation. 


\section{EMPIRICAL RESULTS AND DISCUSSION}

Since the purpose of this section is to present the results of the methodology and their interpretation in the context of the research and the literature, the obtained results are as follows. Firstly, Table 3 indicates the descriptive statistics of all variables of the model.

After a detailed analysis of the movement of indicators by years, the collected data will be summarized by descriptive statistics. There are 100 hotel-firm observations for the period 2015-2019.

Table 3. Descriptive statistics

\begin{tabular}{|l|c|c|c|c|c|}
\cline { 2 - 6 } \multicolumn{1}{c|}{} & $\mathbf{N}$ & Minimum & Maximum & Mean & Std. Deviation \\
\hline EQ & 100 & -8.4885 & 21.8015 & 1.030402 & 3.1186095 \\
\hline Z-Score & 100 & -2.0700 & 13.4700 & 3.118000 & 3.2776991 \\
\hline SZ & 100 & 8.6101 & 15.5446 & 12.920268 & 1.3942531 \\
\hline CL & 100 & 0.0200 & 14.5100 & 1.413200 & 2.4503312 \\
\hline AG & 100 & 1.0986 & 3.6889 & 2.710961 & 0.4832580 \\
\hline ROA & 100 & -106.4200 & 79.4200 & 2.266700 & 19.8121489 \\
\hline LEV & 100 & 3.1800 & 238.6000 & 50.066800 & 41.3355864 \\
\hline Valid N (listwise) & 100 & \multicolumn{4}{ll}{} \\
\hline
\end{tabular}

Source: Authors' calculation, SPSS output

The presented descriptive analysis of analyzed hotels shows the mean value, standard deviation, minimum, and maximum value of the collected research data. Based on 100 observations, the results showed positive mean values for all variables/indicators.

Using a sample of 100 firm-year observations over the period from 2015 to 2019, we examine the practice of earnings management behavior. The result showed low earnings quality (EQ $=$ positive mean values for earnings management is 1.030402). Results of the univariate test suggest that earnings management is significantly different from zero (Table 4).

Table 4. One-Sample test

\begin{tabular}{|c|c|c|c|c|c|c|}
\hline \multicolumn{7}{|c|}{ One-Sample Statistics } \\
\hline & $\mathbf{N}$ & Mean & \multicolumn{2}{|c|}{ Std. Deviation } & \multicolumn{2}{|c|}{ Std. Error Mean } \\
\hline$\overline{\mathbf{E Q}}$ & 100 & 1.0304 & \multicolumn{2}{|c|}{3.11861} & \multicolumn{2}{|c|}{3.1186} \\
\hline \multicolumn{7}{|c|}{ One-Sample Test } \\
\hline & \multicolumn{6}{|c|}{ Test Value $=0$} \\
\hline & \multirow[t]{2}{*}{$\mathbf{t}$} & \multirow[t]{2}{*}{ df } & \multirow[t]{2}{*}{ Sig. (2-tailed) } & \multirow{2}{*}{$\begin{array}{c}\text { Mean } \\
\text { Difference }\end{array}$} & \multicolumn{2}{|c|}{$\begin{array}{l}\text { 95\% Confidence Interval of } \\
\text { the Difference }\end{array}$} \\
\hline & & & & & Lower & Upper \\
\hline EQ & 3.304 & 99 & 0.001 & 1.03040 & 0.4116 & 1.6492 \\
\hline
\end{tabular}

Source: Authors' calculation, SPSS output

If Serbian hotels are engaged in earnings management, we expect earnings quality (EQ) measured by the Miller Ratio to be significantly different from zero. Therefore, hypothesis one $\left(H_{1}\right)$ is confirmed. There are significant statistical indicators of earnings management practices in Serbian hotels during the period 2015-2019 (Presented Sig. value $($ Sig. $=0.001<0.05)$. The presented findings in this subsection are consistent with the existing research of earnings management around emerging countries (Callao, Jarne, \& Wróblewski, 2019). 
Table 5 shows the results of Pearson correlation coefficients between the dependent variable (EQ) and all independent variables.

Table 5. Correlation matrix

\begin{tabular}{|c|c|c|c|c|c|c|c|c|}
\hline \multicolumn{9}{|c|}{ Correlations } \\
\hline & & EQ & Z-Score & SZ & LC & AG & ROA & LEV \\
\hline \multirow{3}{*}{ Z-Score } & \begin{tabular}{|l} 
Pearson \\
Correlation
\end{tabular} & 0.151 & 1 & -0.009 & $0.732^{* *}$ & $0.375^{* *}$ & $0.197^{*}$ & $-0.646^{* *}$ \\
\hline & $\mathrm{N}$ & 100 & 100 & 100 & 100 & 100 & 100 & 100 \\
\hline & Sig. (2-tailed) & 0.133 & & 0.932 & 0.000 & 0.000 & 0.049 & 0.000 \\
\hline \multirow{3}{*}{ LC } & $\begin{array}{l}\text { Pearson } \\
\text { Correlation }\end{array}$ & 0.032 & $0.732^{* *}$ & -0.079 & 1 & $0.283^{* *}$ & 0.052 & $-0.381^{* *}$ \\
\hline & $\mathrm{N}$ & 100 & 100 & 100 & 100 & 100 & 100 & 100 \\
\hline & Sig. (2-tailed) & 0.753 & 0.000 & 0.432 & & 0.004 & 0.609 & 0.000 \\
\hline \multirow{3}{*}{ ROA } & $\begin{array}{l}\text { Pearson } \\
\text { Correlation }\end{array}$ & $0.388^{* *}$ & $0.197^{*}$ & 0.155 & 0.052 & -0.021 & 1 & $-0.437^{* *}$ \\
\hline & $\mathrm{N}$ & 100 & 100 & 100 & 100 & 100 & 100 & 100 \\
\hline & Sig. (2-tailed) & 0.000 & 0.049 & 0.123 & 0.609 & 0.834 & & 0.000 \\
\hline \multirow{3}{*}{ LEV } & $\begin{array}{l}\text { Pearson } \\
\text { Correlation }\end{array}$ & -0.129 & $-0.646^{* *}$ & $-0.279^{* *}$ & $-0.381^{* *}$ & $-0.320^{* *}$ & $-0.437^{* *}$ & 1 \\
\hline & $\mathrm{N}$ & 100 & 100 & 100 & 100 & 100 & 100 & 100 \\
\hline & Sig. (2-tailed) & 0.201 & 0.000 & 0.005 & 0.00 & 0.001 & 0.000 & \\
\hline \multirow{3}{*}{ EQ } & $\begin{array}{l}\text { Pearson } \\
\text { Correlation }\end{array}$ & 1 & 0.151 & $0.310^{* *}$ & 0.032 & $0.197^{*}$ & $0.388^{* *}$ & -0.129 \\
\hline & $\mathrm{N}$ & 100 & 100 & 100 & 100 & 100 & 100 & 100 \\
\hline & Sig. (2-tailed) & & 0.133 & 0.002 & 0.753 & 0.050 & 0.000 & 0.201 \\
\hline \multirow{3}{*}{ SZ } & $\begin{array}{l}\text { Pearson } \\
\text { Correlation } \\
\end{array}$ & $0.310^{* *}$ & -0.009 & 1 & -0.079 & $0.355^{* *}$ & 0.155 & $-0.279^{* *}$ \\
\hline & $\mathrm{N}$ & 100 & 100 & 100 & 100 & 100 & 100 & 100 \\
\hline & Sig. (2-tailed) & 0.002 & 0.932 & & 0.432 & 0.000 & 0.123 & 0.005 \\
\hline \multirow{3}{*}{ AG } & \begin{tabular}{|l|} 
Pearson \\
Correlation \\
\end{tabular} & $0.197^{*}$ & $0.375^{* *}$ & $0.355^{* *}$ & $0.283^{* *}$ & 1 & -0.021 & $-0.320^{* *}$ \\
\hline & $\mathrm{N}$ & 100 & 100 & 100 & 100 & 100 & 100 & 100 \\
\hline & Sig. (2-tailed) & 0.050 & 0.000 & 0.000 & 0.004 & & 0.834 & 0.001 \\
\hline \multicolumn{9}{|c|}{ ** $\quad$ Correlation is significant at the 0.01 level (2-tailed). } \\
\hline
\end{tabular}

Source: Authors' calculation, SPSS output

The Pearson correlation coefficients ( $\mathrm{r}$ ) can only take values from 1 to +1 . The sign indicates whether the correlation is positive (both variables together decrease and increase) or negative (one variable decreases when the other increases). The absolute value of this coefficient (when we ignore its sign) indicates the strength of the connection. Various authors give different interpretations; however, Cohen (1988) provides the following guidelines for the magnitude of correlation coefficients:

1. small $\mathrm{r}=0.10$ to 0.29

2. mean $\mathrm{r}=0.30$ to 0.49

3. large $r=0.50$ to 1.0 .

In order to identify potential multicollinearity between independent variables, the empirical study includes Variance Inflation Factor test. 
Table 6. Multicollinearity test

\begin{tabular}{|c|c|c|}
\hline \multicolumn{3}{|c|}{ Collinearity Statistics } \\
\hline Variable & Tolerance & VIF \\
\hline Z-Score & 0.285 & 3.515 \\
\hline SZ & 0.733 & 1.364 \\
\hline CL & 0.446 & 2.244 \\
\hline AG & 0.704 & 1.420 \\
\hline ROA & 0.767 & 1.304 \\
\hline LEV & 0.421 & 2.375 \\
\hline Mean & 0.559 & 2.037 \\
\hline
\end{tabular}

Source: Authors' calculation, SPSS output

The table above shows that all VIF values are less than 10 and that all Tolerance values are greater than 0.1 . The results of the VIF test confirmed that there is no high correlation between these variables. It implies that variable selection is appropriate and the model satisfies the condition of multicollinearity absence which is one of the fundamental assumptions in econometric analysis.

The next table shows the multiple linear regression model summary.

Based on the results of the multiple regression model, R-square is 0.287 which implies that the model explained $28.70 \%$ of independent variables variations. The adjusted coefficient of determination (Adjusted $R$ Square) shows that $24.1 \%$ of the variability of the dependent variable - earnings quality (EQ) can be explained by the regression model. However, low adjusted R Square values mean that those firm characteristics cannot explain a lot of reasons for earnings quality. There are also other factors (market variables, corporate governance, business strategy, audit function, institutional factors, etc.) that also have to be included in the explanation of magnitude and direction of earnings quality of Serbian hotels (Morteza, \& Daryosh, 2014; Klein, 2002; Caramanis, \& Lennox, 2008; Leuz, Nanda, \& Wysocki, 2003). Sink and Tuttle (1989) mention that performance should not be evaluated only through financial indicators, therefore non-financial indicators should be taken into consideration (customer satisfaction, employee satisfaction, etc.) (Avci, Madanoglu, \& Okumus, 2011).

Table 7. Summary of the regression model

\begin{tabular}{|c|c|c|c|c|c|c|c|c|c|c|}
\hline \multicolumn{11}{|c|}{ Model Summary } \\
\hline \multirow[b]{2}{*}{ Model } & \multirow[b]{2}{*}{$\mathbf{R}$} & \multirow[b]{2}{*}{$\begin{array}{c}\mathbf{R} \\
\text { Square }\end{array}$} & \multirow[b]{2}{*}{$\begin{array}{c}\text { Adjusted R } \\
\text { Square }\end{array}$} & \multirow[b]{2}{*}{$\begin{array}{l}\text { Std. Error } \\
\text { of the } \\
\text { Estimate }\end{array}$} & \multicolumn{5}{|c|}{ Change Statistics } & \multirow[b]{2}{*}{$\begin{array}{l}\text { Durbin- } \\
\text { Watson }\end{array}$} \\
\hline & & & & & $\begin{array}{c}\text { R } \\
\text { Square } \\
\text { Change }\end{array}$ & $\begin{array}{c}F \\
\text { Change }\end{array}$ & df1 & df2 & $\begin{array}{l}\text { Sig. F } \\
\text { Change }\end{array}$ & \\
\hline 1 & $0.536^{\mathrm{a}}$ & 0.287 & 0.241 & 93.7687153 & 0.287 & 6.233 & 6 & 93 & 0.000 & 2.380 \\
\hline a & edictor: & : (Consta & t), LEV, SZ, & $\mathrm{G}, \mathrm{ROA}, \mathrm{CL}$ & $Z$ score & & & & & \\
\hline
\end{tabular}

Source: Authors' calculation, SPSS output

The Durbin-Watson $\mathrm{d}=2.380$, which is between the two critical values of $1.5<\mathrm{d}<2.5$ (Kalayci, 2005). Therefore, we can assume that there is no first-order linear auto-correlation in our multiple linear regression data.

The next output table is the F-test. The linear regression's F-test has the null hypothesis that the model explains zero variance in the dependent variable (in other words $\mathrm{R}^{2}=0$ ). 
Table 8. ANOVA results

\begin{tabular}{|c|c|c|c|c|c|c|}
\hline \multicolumn{9}{|c|}{ ANOVA $^{\mathbf{a}}$} & \multirow{2}{*}{ Sig. } \\
\hline \multirow{2}{*}{1} & Model & $\begin{array}{c}\text { Sum of } \\
\text { Squares }\end{array}$ & df & Mean Square & F & 0.000 \\
\cline { 2 - 8 } & Regression & 328827.691 & 6 & 54804.615 & 6.233 & \\
\cline { 2 - 8 } & Residual & 817709.193 & 93 & 8792.572 & & \\
\cline { 2 - 8 } & Total & 1146536.884 & 99 & & & \\
\hline \multicolumn{7}{|l|}{ Dependent Variable: EQ }
\end{tabular}

Source: Authors' calculation, SPSS output

Presented Sig. values $($ Sig. $=0.000<0.05)$ in Table 8 suggest that our model is significant.

The next table shows the multiple linear regression estimates including the intercept and the significance levels.

Table 9. The Coefficients of regression model

\begin{tabular}{|c|c|c|c|c|c|c|c|c|}
\hline \multicolumn{9}{|c|}{ Coefficients ${ }^{\mathrm{a}}$} \\
\hline \multirow[t]{2}{*}{ Mode } & \multirow[b]{2}{*}{ B } & \multicolumn{2}{|c|}{$\begin{array}{c}\text { Unstandardized } \\
\text { Coefficients } \\
\end{array}$} & \multirow[t]{2}{*}{$\begin{array}{c}\text { Standardized } \\
\text { Coefficients }\end{array}$} & \multirow{2}{*}{ t } & \multirow{2}{*}{$\begin{array}{l}\text { Sig. } \\
\text { Lower } \\
\text { Bound }\end{array}$} & \multicolumn{2}{|c|}{$\begin{array}{l}\mathbf{9 5 , 0} \% \text { Confidence } \\
\text { Interval for B }\end{array}$} \\
\hline & & Std. Error & Beta & & & & Upper & \\
\hline \multirow{7}{*}{1} & (Constant) & -454.566 & 108.892 & & -4.174 & 0.000 & -670.804 & -238.327 \\
\hline & Z-Score & 10.860 & 5.390 & 0.331 & 2.015 & 0.047 & 0.156 & 21.565 \\
\hline & SZ & 22.537 & 7.895 & 0.292 & 2.855 & 0.005 & 6.859 & 38.214 \\
\hline & CL & -4.769 & 5.761 & -0.109 & -0.828 & 0.410 & -16.209 & 6.672 \\
\hline & AG & 27.486 & 23.235 & 0.123 & 1.183 & 0.240 & -18.654 & 73.625 \\
\hline & ROA & 2.400 & 0.543 & 0.442 & 4.419 & 0.000 & 1.322 & 3.479 \\
\hline & LEV & 0.931 & 0.351 & 0.357 & 2.649 & 0.009 & 0.233 & 1.628 \\
\hline
\end{tabular}

Source: Authors' calculation, SPSS output

If we force all variables into the multiple linear regression, we find that the hotel's going concern (Z-Score), size (SZ), return on assets (ROA), and leverage (LEV) are significant predictors. Other factors current liquidity (CL) and age (AG) do not have a significant impact on the earnings quality of the analyzed hotels.

\section{CONCLUSION}

Earning quality is an important measure for the financial health of the business entity/hotel unit. This paper examines the firm-level determinants of earnings quality in the hotel industry. Therefore, the earnings quality is affected by reports and manager's discretion and their ability. We concluded that particular characteristics of the company such as hotel's going concern (Z-Score), size (SZ), return on assets (ROA), leverage (LEV) are the major determinant of earnings quality in the hotel industry. The data available could only allow a period coverage of 5 years; possibly a large period could have yielded more relevant results.

Our research has potential, as there is not a lot written about earnings quality in the Western Balkans. The study used a quantitative approach in collecting hotel sector data based on financial statements of 20 hotels/ business entities registered in Serbia. We consider the 100 firmyear observations from 2015-2019. There are many recognized methods, which can be used when measuring the existence of earnings management. In this paper, the Miller (2009) Model 
was used to measure earnings quality and detect earnings management in financial statements. Based on the results, we do not reject hypothesis one (H1) that Serbian hotels have a low quality of accounting earnings during the period 2015-2019.

The study aimed to examine the impact of financial performances on the earnings quality of Serbian hotels. Based on empirical results, the authors found a significant positive correlation between earnings quality (EQ) and the hotel's going concern (Z-Score), size (SZ), return on assets (ROA), leverage (LEV). Therefore, hypothesis two $\left(\mathrm{H}_{2}\right)$ is confirmed. The financial performances of Serbian hotels are associated with the quality of accounting earnings.

\section{FUTURE RESEARCH DIRECTIONS}

This research has been conducted on the emerging Serbian market. The results of this study produced implications for managers, investors, creditors, regulators, and other users of financial statements. It is suggested that future researchers investigate the relationship of the following parameters with earning quality in their future:

1. The impact of change in accounting standards on earnings quality,

2. The relationship of reporting type and audit quality with earning quality,

3. The effect of earning quality on the accuracy of earning predicting,

4. The impact of market variables, corporate governance, business strategy, institutional factors, etc. on earning quality,

5. Measuring earnings quality using different accruals approach.

Despite these limitations, the results of this study are important to different users of financial statements and researchers who study the problem of earnings management in emerging economies. This research contributes to the earnings management literature by examining a specific hotel industry.

\section{REFERENCES}

Aharony, J., Barniv, R., \& Falk, H. (2010). The impact of mandatory IFRS adoption on equity valuation of accounting numbers for security investors in the EU. European Accounting Review, 19(3), 535-578.

Altman, A. (1968). Financial ratios, discriminant analysis and the prediction of corporate bankruptcy. The Journal of Finance, 23(4), 589-609.

Anwer, S.A., Michael J.N., \& Dechun, W. (2013). Does mandatory adoption of IFRS improve accounting quality? Preliminary Evidence. Contemporary Accounting Research, 30(4), 1344-1372.

Avci, U., Madanoglu, M., \& Okumus F. (2011). Strategic orientation and performance of tourism firms: Evidence from a developing country. Tourism Management, 32(1), 147-157.

Ball, R., Robin, A., \& Wu, J.S. (2003). Incentives versus standards: properties of accounting income in four East Asian countries. Journal of Accounting and Economics, 36(1), 235-270. DOI: 10.1016/j. jacceco.2003.10.003.

Barker, R., \& Imam, S. (2008). Analysts' perceptions of earnings quality. Accounting and Business Research, 38(4), 313-329.

Baxter, P., \& Cotter, J. (2009). Audit committees and earnings quality. Accounting \& Finance, 49(2), 267290.

Becker, C.L., DeFond, M.L., Jiambalvo, J., \& Subramanyam, K.R. (1998). The effect of audit quality on earnings management. Contemporary Accounting Research, 15(1), 1-24.

Biddle, G.C., Hillary, G., \& Verdi, R.S. (2009). How does financial reporting quality relate to investment efficiency. Journal of Accounting and Economics, 43(2-3), 112-131. 
Bodie, Z., Kane, A., \& Marcus, A.J. (2013). Investments, Singapore: Global Edition ed., McGraw-Hill/ Irwin.

Burca, V., \& Mates, D. (2015). Implications of IFRS adoption on earnings quality, empirical case for Romanian environment. Annales Universitatis Apulensis Series Oeconomica, 1(17), 1-5.

Callao, S., Jarne, J., \& Wroblewski, D. (2014a). Debates and studies on earnings management: a geographical perspective. Theoretical Journal of Accounting (Zeszyty Teoretyczne Rachunkowości), 75, 145169.

Callao, S., Jarne, J., \& Wroblewski, D. (2014b). The development of earnings management research. A review of literature from three different perspectives. Theoretical Journal of Accounting (Zeszyty Teoretyczne Rachunkowości), 79, 135-177.

Callao, S., Jarne, J.I., \& Wróblewski, D. (2019). A new perspective on earnings management in emerging European countries: Investigation on environmental factors that explain differences in earnings management. Journal of Accounting, Business and Finance Research, 7(2), 59-81.

Caramanis, C., \& Lennox, C. (2008). Audit effort and earnings management. Journal of Accounting and Economics, 45, 116-138.

Center for the Financial Reporting Reform. (2015). Report on the Observance of Standards and Codes on Accounting and Auditing - Republic of Serbia. Vienna, Austria: World Bank

Chan, K., Chan, L., Jegadeesh, L. \& Lakonishok, J. (2006). Earnings quality and stock returns. Journal of Business, 79, 1041-1082.

Chung, R., Firth, M., \& Kim, J.B. (2002). Institutional monitoring and opportunistic earnings management. Journal of Corporate Finance, 8(1), 29-48.

Cohen, J.W. (1988). (2nd ed.). Statistical Power Analysis for the Behavioral Sciences. Hillsdale, NJ: Lawrence Erlbaum Associates.

Deegan, C. (1996). Australian Financial Accounting, Sydney: McGraw-Hill.

Djate, A., Gao, G., Sarikas, R., Senteney, L.D. (2011). Eastern and Western European firms public and private information quality: The comparative impact of degree of implementation of IFRS. Emerging Markets Review, 12(2), 111-129.

Gaio, C. (2010). The relative importance of firm and country characteristics for earnings quality around the world. European Accounting Review, 19(4), 693-738.

Gombolaa, J.M., Amy, H., Chin-Chuan, H. (2016). The effect of leverage and liquidity on earnings and capital management: Evidence from U.S. commercial banks. International Review of Economics and Finance, 43(1), 35-58. https://doi.org/10.1016/j.iref.2015.10.03.

Hai-Yen C., Li-Heng L., Hui-Fun Y. (2019). Market power, competition and earnings management: accrual-based activities. Journal of Financial Economic Policy, 11(3), 368-384.

Healy, P.M. (1999). Discussion of earnings-based bonus plans and earnings management by business unit managers. Journal of Accounting and Economics, 26(1-3), 143-147.

Iatridis, G., \& Kadorinis, G. (2009). Earnings management and firm financial motives: A financial investigation of UK listed firms. International Review of Financial Analysis, 18(4), 164-173.

Indracahya, E., \& Anggraini, D. (2017). The effect of good corporate governance elements, leverage, firm age, company size and profitability on earning management (empirical study of manufacturing companies in Bei 2014 - 2016). Profita, 10(2), 203-227.

Itoh, K. (2007). Corporate Valuation, Tokyo: Nihon Keizai Shimbun-sha.

Jayaraman, S. (2008). Earnings volatility, cash flow volatility, and informed trading. Journal of Accounting Research, 46(4), 809-851.

Kalaš, B., Mirović, V., Pavlović, N. (2019). Profitability determinants of hotel industry in AP Vojvodina. In V. Bevanda \& S. Štetić (Eds.), 4th International Thematic Monograph: Modern Management Tools and Economy of Tourism Sector in Present Era (pp. 47-62). Belgrade: Association of Economists 
and Managers of the Balkans with Faculty of Tourism and Hospitality, Ohrid, North Macedonia. https://doi.org/10.31410/tmt.2019.

Kalayci, S. (2005). (1st ed.). SPSS Applications, Multi-variables Statistics Techniques. Ankara Turkey: Asil Publish.

Khalil, M. \& Simon, J. (2014). Efficient contracting, earnings smoothing and managerial accounting discretion. Journal of Applied Accounting Research, 15 (1), 100-123.

Kirschenheiter, M., \& Melumad, N. (2004). Earnings' quality and smoothing. Working paper Columbia Business School. Retrieved from: https://pdfs.semanticscholar.org/71eb/7322d59bee32d20ec789cd809575eedea9d7.pdf.

Klein, A. (2002). Audit committee, board of director characteristics, and earnings management. Journal of Accounting and Economics, 33(3), 375-401.

Koch, B.S. (1981). Income smoothing: An experiment. The Accounting Review, 56, 574-586.

Leuz, C., Nanda, D.J., \& Wysocki, P. (2003). Earnings management and investor protection: An international comparison. Journal of Financial Economics, 69(3), 505-527.

Miller, E.J. (2009). The development of the Miller ratio (MR): A tool to detect for the possibility of earnings management (EM). Journal of Business \& Economics Research, 7(1), 79-90.

Mohammadi, F., \& Amini, P. (2016). Investigating the Relationship between financial distress and earnings management in corporations of accepted in Tehran Stock Exchange. International Academic Journal of Accounting and Financial Management, 3(6), 41- 50.

Morteza, A., Daryosh J., \& Hosin S. (2014). The relationship between pay policy dividends and earnings quality firms. International Research Journal of Applied and Basic Sciences, 8(6), 667-674.

Park, Y.W., \& Shin, H.H. (2004). Board Composition and Earnings Management in Canada. Journal of Corporate Finance, 10(3), 431-457.

Parte-Esteban, L., \& Devesa, M.J. (2011). Earnings management in the Spanish hotel industry. Cornell Hospitality Quarterly, 52(4), 466-479.

Rahman, M.M., Moniruzzaman, M., \& Sharif, M.J. (2013). Techniques, motives and controls of earnings management. International Journal of Information Technology and Business Management, 11(1), 22-34.

Ratnanigrum, R. (2016). The influence of profitability and income tax on income smoothing rankings. Jurnal Bisnis \& Manajemen, 17(2), 133-143.

Ronen, J., Tzur, J., \& Yaari, V. L. (2006). The effect of directors' equity incentives on earnings management. Journal of Accounting and Public Policy, 25(4), 359-389.

Roychowdhury, S. (2006). Earnings management through real activities manipulation. Journal of Accounting and Economics, 42(3), 335-370.

Schipper, K. (1989). Commentary on earnings management. Accounting Horizons, 3(4), 91-102.

Scott, W.R. (2009). (Fifth ed.). Financial accounting theory. Prentice Hall, New Jersey: Upper Saddle River.

Tapia, A.B., \& Taskón Fernández, M. (2011). Accruals, cash flows and earnings in European privately held firms. Pecvnia Monográfico, 133-156.

Watts, R., \& Zimmerman, J. (1986). Positive accounting theory, Englewood Cliffs, New Jersey: Prentice Hall.

Watts, R.L. \& Zimmerman, J.L. (1990). Positive accounting theory: A ten year perspective. Accounting Review, 65(1), 131-156.

Wijesinghe, R., \& Kehelwalatenna, S. (2017). The impact of earnings quality on the stock returns of listed manufacturing companies in the Colombo Stock Exchange. Colombo Business Journal International Journal of Theory and Practice, 8(2), 69-89.

Wruck, K. H. (1990). Financial distress, reorganization, and organizational efficiency. Journal of Financial Economics, 27(2), 419-444. 
